\title{
Analysis of growing degree-days as a climate impact indicator in a region with extreme annual air temperature amplitude
}

\author{
E. A. Grigorieva ${ }^{1, *}$, A. Matzarakis ${ }^{2}$, C. R. de Freitas ${ }^{3}$ \\ ${ }^{1}$ Institute for Complex Analysis of Regional Problems, Far Eastern Branch Russian Academy of Sciences, 679016, \\ 4, Sholom-Aleikhem St., Birobidzhan, Russia \\ ${ }^{2}$ Meteorological Institute, Albert-Ludwigs-University of Freiburg, 79085 Freiburg, Germany \\ ${ }^{3}$ School of Environment, University of Auckland, PB 92019 Auckland, New Zealand
}

\begin{abstract}
We used the concept of growing degree-days (GDD) as a measure of the agricultural potential of climate on a regional scale in the southern part of the Russian Far East, the climate of which is characterized by thermal extremes. Daily maximum and minimum air temperatures were used to calculate GDD at 17 locations using threshold base air temperatures of $0,5,10$ and $15^{\circ} \mathrm{C}$, with a high-temperature threshold cut-off of $30^{\circ} \mathrm{C}$. GDD increased from north to south in the study area, but the mean GDD varied considerably from one location to another. Marginal thermal conditions were observed in the north, both in the elevated areas and in the coastal regions. There was a high correlation between GDD and mean monthly temperature for the growing season from May to September (T59), such that the latter can be used as a proxy for GDD, which has implications for agricultural management. GDD and T59 had an upward trend over the 1966-2005 period for the study region as a whole. The most significant upward trend was observed for GDD0, while results for GDD15 exhibit little or no trend.
\end{abstract}

KEY WORDS: Growing degree-days $\cdot$ Climate change $\cdot$ Spatial and temporal analysis $\cdot$ Russian Far East $\cdot$ Climate and agriculture $\cdot$ Agro-climate indices $\cdot$ Biologically active temperature

\section{INTRODUCTION}

Many environmental factors affect the distribution, growth and biological development of plants, but most relate to climate (Wiggans 1956, Brown 1960, Chirkov 1965, Edey 1977, Idso et al. 1978, Russelle et al. 1984, McMaster \& Smika 1988, Gordon \& Bootsma 1993, Karing et al. 1999, Wielgolaski 1999, Førland et al. 2004, Gavilán 2005). In terms of climatic indictor variables based on standard climate data, air temperature and precipitation are the most important. The former is particularly important because it is linked both directly and indirectly to other indicators such as soil temperature, day length (photoperiod) and solar radiation. Moreover, the cumulative effect of daily air temperature over the longer term is an important indicator of plant growth potential and crop yield (Wang 1960, Idso et al. 1978, Schwartz et al. 2006). It has been found to statistically explain $95 \%$ of the variability in plant development (Russelle et al. 1984). Temperature is also the main limiting factor for plant growth, especially in temperate zones and at high latitudes (Wiggans 1956, Førland et al. 2004).

Various climatic indices based on air temperature that show the heat accumulation necessary for plant development have been proposed for use primarily in agricultural management processes (Cross \& Zuber 1972, Bootsma 1994, Dwyer et al. 1999, Snyder et al. 1999, Bootsma et al. 2004, Gavilán 2005, Gordeev et al. 2006). The notion of accumulated heat units was introduced almost 300 yr ago by the French scientist R. A. F. de Réaumur (Wang 1960, Mederski et al. 1973). Agro- 
climatic indices used to quantify the rate of development of crops have evolved from this. They include simple heat units based on the accumulation of daily mean temperatures above a certain threshold temperature during growing period (Wiggans 1956, Brown 1960, Wang 1960, Baskerville \& Emin 1969, Chen 1973). Others are: the sum of effective temperatures (Chirkov 1965, Gordeev et al. 2006); effective degrees (Gilmore \& Rogers 1958); the accumulated heat unit (Mederski et al. 1973); growing degree units (Darby \& Lauer 2002); P-days, which is a heat unit for the growth and development of potatoes (Sands et al. 1979); corn heat units, used to define the relationship between temperature and the development of corn hybrids (Smith et al. 1982, Bootsma 1994, Dwyer et al. 1999, Bootsma et al. 2004); the general thermal index, developed from statistically fitted maize development temperature response functions for the vegetative and grain-filling periods (Dwyer et al. 1999); and photothermal units (McMaster \& Smika 1988).

There have been other approaches. One method calculates sums of positive temperatures over a period above a given threshold temperature $\left(T_{\text {base }}\right)$, referred to as active temperatures for the growth period starting from the date of the onset of spring (e.g. Davitaya 1965, Kelchevskaya 1971, Karing et al. 1999, Gordeev et al. 2006). The sum of biologically active temperatures $\left(T_{\text {ac }}\right)$ is given as:

$$
T_{\mathrm{ac}}=\sum_{i=1}^{n} T_{i}
$$

where $T_{i}$ is mean daily temperature $\left({ }^{\circ} \mathrm{C}\right)$ and $i=1,2 \ldots n$ is the number of days with mean temperature above the respective threshold or base temperature $\left(T_{\text {base }}\right)$, marking the start of the growing season (Table 1). The concept of active temperatures is very similar to the widely used growing degrees-days (GDD), but is not the same. In the case of $T_{\text {ac }}$ all positive temperatures under the diurnal temperature curve are summed during the period with temperatures above the respective threshold. For the calculation of GDD, days with temperatures above the base threshold inside this period are summed. The main difference is that in the case of $T_{\text {acr }}$ all of the heat supply above $0^{\circ} \mathrm{C}$ is assessed, whereas for GDD, only the heat supply above a given base threshold is accounted for (Fig. 1).

The GDD concept recognizes that plant development will occur only when the temperature exceeds a specific base temperature for a certain number of days. It is a measure of the heat a plant requires to mature and yield a successful crop. It neglects additional environmental factors and different responses of plants to the same temperature during various stages of their life cycle, but it has been widely used due to practical utility in agricultural, phenological and other studies (Wang 1960). GDDs are used to predict the growth
Table 1. Indicative lower base temperatures ( $\left.T_{\text {base }}\right)$ for various crops

\begin{tabular}{|c|c|c|}
\hline Crop & $T_{\text {base }}\left({ }^{\circ} \mathrm{C}\right)$ & Source \\
\hline Brussels sprouts & 0 & Edey (1977) \\
\hline Parsley & 0 & Edey (1977) \\
\hline Cabbage & 0 & Edey (1977) \\
\hline Winter wheat & 0 & McMaster \& Smika (1988) \\
\hline Oats & 4.5 & Wiggans (1956) \\
\hline Peas & 4.5 & Wang (1960) \\
\hline Peas & 5 & $\begin{array}{l}\text { Edey (1977), Bootsma et al. } \\
(2004), \text { Jones \& Briffa (1995) }\end{array}$ \\
\hline Perennial forage crops & s 5 & $\begin{array}{l}\text { Bootsma et al. (2004), } \\
\text { Førland et al. (2004) }\end{array}$ \\
\hline Wheat & 5.5 & Idso et al. (1978) \\
\hline $\begin{array}{l}\text { Perennial forage crops } \\
\text { (pasture grasses) }\end{array}$ & 5.5 & Bootsma (1994) \\
\hline Potatoes & 7 & Sands et al. (1979) \\
\hline Corn (maize) & 10 & $\begin{array}{l}\text { Gilmore \& Rogers (1958), } \\
\text { Wang (1960), Cross \& Zuber } \\
\text { (1972), Mederski et al. (1973), } \\
\text { Edey (1977), Dwyer et al. } \\
\text { (1999), Cesaraccio et al. } \\
\text { (2001), Darby \& Lauer (2002) }\end{array}$ \\
\hline Soybean & 10 & Brown (1960), Edey (1977) \\
\hline Sugar beet & 10 & $\begin{array}{l}\text { Davitaya (1965), Baskerville } \\
\text { \& Emin (1969) }\end{array}$ \\
\hline Sunflowers & 10 & $\begin{array}{l}\text { Davitaya (1965), Baskerville } \\
\text { \& Emin (1969) }\end{array}$ \\
\hline Tomatoes & 10 & Edey (1977) \\
\hline Corn hybrids & 11.1 & Smith et al. (1982) \\
\hline
\end{tabular}

stages of major crops, temperate latitude crops in particular, such as soya bean, maize and wheat; it is also useful in planning precautionary measures against insect pest and disease attacks on crops (Gilmore \& Rogers 1958, Wang 1960, Baskerville \& Emin 1969, Smith et al. 1982, Russelle et al. 1984, McMaster \& Smika 1988, Gordon \& Bootsma 1993, Bootsma 1994, McMaster \& Wilhelm 1997, Dwyer et al. 1999, Roltsch et al. 1999, Cesaraccio et al. 2001, Førland et al. 2004,

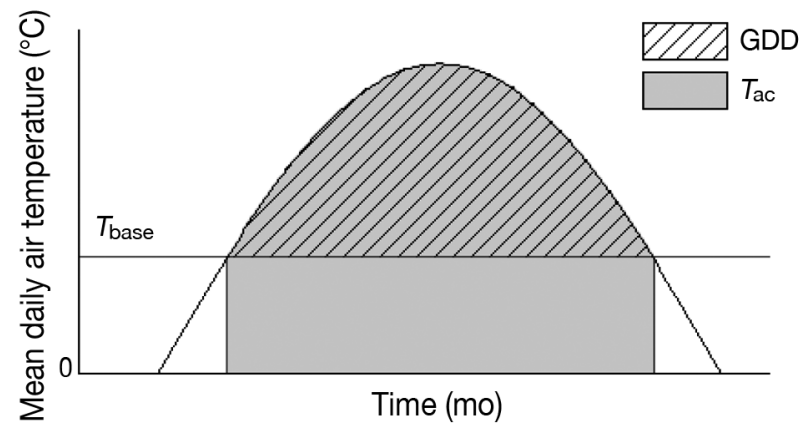

Fig 1. Schematic representation of 2 different approaches used to integrate thermal climatic conditions relevant to plant growth and development. A threshold or base temperature ( $\left.T_{\text {base }}\right)$ is used define the beginning and end of an appropriate growing season, which is described as accumulations of biologically active temperature $\left(T_{\mathrm{ac}}\right)$ or growing degree-days (GDD) using mean daily climatic data. For illustrative purposes, the annual temperature cycle is shown as a sine curve 
Matzarakis et al. 2007, Fealy \& Fealy 2008). The GDD index is derived from standard climate station data and may be based on long-term mean daily temperatures; alternatively, it may be calculated from data for a given year, in which case it will take into account weather variability and is used to explain seasonal and year-toyear changes in crop yield and, therefore, economic performance. GDD is a useful climate-impact indicator as it provides objective information to users whose activities require them to manage climate risks and opportunities; additionally, GDD could provide insight from historical trends and help predict the effects of climate fluctuation or change on present-day agricultural practices (Easterling \& Kates 1995).

In the past, it appears most analyses of regional temperature series have used time series of monthly mean temperatures or growing season averages (Folland et al. 1990, 1992, Jones \& Briffa 1992, Karl et al. 1993, Jones 1994). Few analyses have been undertaken with daily time series. Analyses of daily data may produce results that are quite different to inferences based on analyses of monthly mean statistics (Jones \& Briffa 1995). For example, Vedin (1990) found that the growing season in Scandinavia was longer during the cooler 1979-1988 decade compared to the warmer decade of 1931-1940, demonstrating the point 'that it is extremes rather than averages that create limits in nature' (Vedin 1990 , p. 155). With this in mind, the present study determined the utility of GDD as an agro-climate indicator for a thermally extreme midlatitude climate for which this has not previously been studied. We derived daily time series for climate stations for that part of the Russian Far East with the most extreme annual temperature amplitude-namely, the southern part-and explored how this data is related to the mean temperature over the growing season.

A further consideration is that - for the vast majority of national economies - agriculture is the economic sector that is most directly exposed to the vagaries of climate, and is therefore also likely to be most vulnerable to climate change and variability, whether natural or humancaused. However, there is considerable disagreement about the magnitude of potential impacts. To assess the impact of change, one must first gauge the significance of current climate to agriculture, and much depends on the choice of an appropriate climatic metric. A regional assessment of GDD may be useful in this regard.

\section{METHODS}

\subsection{Calculating GDD}

There are several methods of GDD calculation, including estimation using models, each of which have advantages as well as shortcomings (Roltsch et al. 1999). The approach using hourly air temperature data is the most accurate, and only needs data from an automatic weather network (Cesaraccio et al. 2001). The method of GDD with mean air temperature calculated as the average of minimum and maximum daily temperatures is the most common in agricultural and phenological research (Gilmore \& Rogers 1958, McMaster \& Smika 1988, Bootsma 1994, McMaster \& Wilhelm 1997, Dwyer et al. 1999, Matzarakis et al. 2007, Fealy \& Fealy 2008). The method that uses $3 \mathrm{~h}$ interval temperatures to estimate mean temperature arrives at the average of 8 daily temperature ratings (Gilmore \& Rogers 1958, Davitaya 1965, Gordeev et al. 2006, Grigorieva 2008).

The simplest form of GDD is calculated by:

$$
\begin{gathered}
\text { GDD }=\sum_{i=1}^{m}\left(T_{i}-T_{\text {base }}\right) \\
T_{i}=\left(T_{\max }+T_{\min }\right) / 2
\end{gathered}
$$

where $T_{i}$ is the mean air temperature $\left({ }^{\circ} \mathrm{C}\right)$ on the $i$ th day of the growing season, where $i=1,2, \ldots m$ days with a temperature higher than the base or threshold temperature $\left(T_{\text {base, }}{ }^{\circ} \mathrm{C}\right)$ during the growing season, and $T_{\max }$ and $T_{\min }$ are the daily maximum and minimum air temperatures $\left({ }^{\circ} \mathrm{C}\right)$, respectively (McMaster \& Smika 1988, Gordon \& Bootsma 1993, Bootsma 1994, McMaster \& Wilhelm 1997, Snyder et al. 1999). In this way, all temperatures under the diurnal temperature curve and over the threshold value are summed (see Fig. 1).

GDDs required to reach maturity of the specific crop are calculated from:

$$
\mathrm{GDD}=\sum_{i=n}^{m}\left(T_{i}-T_{\text {base }}\right)
$$

where, in contrast with Eq. (1), $n$ is the date of planting and $m$ is the date of maturity (Dwyer et al. 1999), or $n$ is the day beginning at growth stage $s_{1}$ and $m$ is the beginning of growth stage $s_{2}$ (McMaster \& Smika 1988).

\subsection{Lower and upper thresholds}

Plants have adapted to grow best above a certain temperature, below which there is no plant development. Each crop type has its own base temperature threshold ( $T_{\text {base }}$ ). Table 1 lists values of $T_{\text {base }}$ for a variety of agricultural crops. Typically, in general assessments of thermal impact on crops, $0,5,10$ and $15^{\circ} \mathrm{C}$ are taken as base or threshold temperatures (Kelchevskaya 1971, Edey 1977, Gordon \& Bootsma 1993, Karing et al. 1999, Gordeev et al. 2006, Fealy \& Fealy 2008, Grigorieva 2008) due to the close relationship of these 
temperature limits with the onset and end of the main crop development. The particular threshold valuesas used in studies by Russian or the former USSR's researchers - are described as follows (Gordeev et al. 2006):

$>0^{\circ} \mathrm{C}$ : commencement of warm season;

$>5^{\circ} \mathrm{C}$ : start of period of active plant growth;

$>10^{\circ} \mathrm{C}$ : beginning of main growth period for the main

cold-resistant wild and cultivated plants;

$>15^{\circ} \mathrm{C}$ : conditions best suited to heat-loving plants.

In the present study, these lower base thresholds were used for all the degree-day calculations.

High air temperatures, as with low temperatures, may drastically reduce plant development and growth rates, or even stop development (Wang 1960, Bootsma 1994, Roltsch et al. 1999, Snyder et al. 1999). Two approaches are used apply upper thermal thresholds in agro-climate indices (Baskerville \& Emin 1969, Roltsch et al. 1999). The first uses a horizontal cut-off in which all temperatures above the upper threshold are considered to have equal value in GDD summations. In the second approach, it is assumed high temperatures stop growth, and no heat units are accumulated for the period when temperatures exceed this upper limit. Baskerville \& Emin (1969) found that the difference between the two is often small and never exceeded $5 \%$ of the accumulated sum of heat units for the data they used. Upper temperature thresholds $\left(T_{\mathrm{UT}}\right)$ for a variety of crops are given in Table 2. Typically, a $T_{\mathrm{UT}}$ of $30^{\circ} \mathrm{C}$ is employed (Table 2). In the present study, the method estimating horizontal high-temperature threshold cut-off, described by Baskerville \& Emin (1969) and Matzarakis et al. (2007), was used with a $T_{\mathrm{UT}}$ of $30^{\circ} \mathrm{C}$. All values of $T_{i,} T_{\max }$ or $T_{\min }$ are reset to $T_{\mathrm{UT}}$ if they exceed $T_{\mathrm{UT}}$ (McMaster \& Wilhelm 1997, Matzarakis et al. 2007).

In the present study, GDD was calculated according Eqs. (1) and (2) using the upper and lower thresholds described above. However, it is necessary to specify which of the 2 methods are used to relate the lower $T_{\text {base }}$ to the term $T_{i}=\left(T_{\max }+T_{\min }\right) / 2$, since differences can result depending on the method used. McMaster \&

Table 2. Indicative upper threshold temperatures ( $T_{\mathrm{UT}}$ ) for selected crops

\begin{tabular}{|c|c|c|}
\hline Crop & $T_{\mathrm{UT}}\left({ }^{\circ} \mathrm{C}\right)$ & Source \\
\hline Wheat & 25 & McMaster \& Smika (1988) \\
\hline $\begin{array}{l}\text { Corn (incl. maize } \\
\text { and corn hybrids) }\end{array}$ & 30 & $\begin{array}{l}\text { Gilmore \& Rogers (1958), } \\
\text { Cross \& Zuber (1972), Smith } \\
\text { et al. (1982), Russelle et al. } \\
\text { (1984), Dwyer et al. (1999), } \\
\text { Darby \& Lauer (2002), } \\
\text { Matzarakis et al. (2007) }\end{array}$ \\
\hline Soybean & 30 & Brown (1960) \\
\hline Potatoes & 30 & Sands et al. (1979) \\
\hline
\end{tabular}

Wilhelm (1997, p. 291) found that not recognizing the discrepancy between the 2 methods 'can result in confusion and add error in quantifying relationships between heat unit accumulation and timing of events in crop development and growth, particularly in crop simulation models'. They assert that the onus is on the researcher to clearly communicate the method of calculating GDD so others can correctly interpret and apply the reported results. According to McMaster \&Wilhelm (1997, p. 293), 'the important distinction between the two methods is when temperatures are compared to the base temperature. In Method 1, the comparison to $T_{\text {base }}$ occurs after calculating, whereas in Method 2 the comparison to $T_{\text {base }}$ is made before calculating $\left(T_{\max }+T_{\min }\right) / 2$ by comparing $T_{\max }$ and $T_{\min }$ to $T_{\text {base }}$ individually'. To estimate GDD in the present study, we used the second method.

\subsection{Estimation of mean daily temperature}

Typically, in Russian investigations, mean daily air temperature $T_{i}$ is calculated using temperatures taken at $3 \mathrm{~h}$ intervals (Kelchevskaya 1971, Gordeev et al. 2006):

$$
T_{i}=\sum_{k=1}^{8} T_{k}
$$

where $T_{k}\left({ }^{\circ} \mathrm{C}\right)$ is air temperature at the standard time of observation and $k=1 \ldots 8$. This is the standard approach in studies by researchers from Russia and the former USSR (Chirkov 1965, Davitaya 1965, Kelchevskaya 1971, Karing et al. 1999, Gordeev et al. 2006, Grigorieva 2008, etc), or those based on data from the Russian weather station network (as in Jones \& Briffa 1995) where $3 \mathrm{~h}$ interval data is used (Eq. 5). Typically, in non-Russian research, $T_{i}$ is calculated as:

$$
T_{i}=\left(T_{\max }+T_{\min }\right) / 2
$$

We found only one case in which $T_{i}$ was arrived at using the mean of 8 daily temperature ratings in comparison with mean of maximum and minimum ratings (Gilmore \& Rogers 1958). Given that data for temperatures at $3 \mathrm{~h}$ intervals (Eq. 5) are not readily available for all weather stations, following Gilmore \& Rogers (1958) we used Eq. (6) due to its simplicity and reliance on the daily minimum and maximum method, along the lines of studies by Chen (1973), Mederski et al. (1973), McMaster \& Smika (1988), Gordon \& Bootsma (1993), Bootsma (1994), McMaster \& Wilhelm (1997), Dwyer et al. (1999), Darby \& Lauer (2002), Bootsma et al. (2004), and Matzarakis et al. (2007). Gilmore \& Rogers (1958) emphasized that using temperatures at 3 $\mathrm{h}$ intervals was slightly superior to daily maximum and minimum readings; however, on the whole they con- 
cluded the difference between 2 methods was very small. This is an important consideration, the veracity of which will be examined in the present study.

\subsection{Study area and data}

The study area was located in the south of the Russian Far East (Fig. 2), the climate of which is midlatitude monsoon, characterized by an extreme continental annual temperature regime. The area covered extends from latitudes 43 to $59^{\circ} \mathrm{N}$ and from longitudes 127 to $143^{\circ} \mathrm{E}$. Table 3 shows that the $1961-1990$ normal annual temperature here varies between $-5.4^{\circ} \mathrm{C}$ at
Ekimchan to $5.7^{\circ} \mathrm{C}$ at Pogranichnyi. The annual temperature ranges from $28.2^{\circ} \mathrm{C}$ over the coastal part of the study area to $52.7^{\circ} \mathrm{C}$ in the continental interior.

The data used for 17 climate stations are daily mean, maximum and minimum air temperature over the period 1966 to 2005. The network of stations is limited but is representative of a range of climate regions of the Russian Far East (Fig. 2), namely: coastal (Okhotsk, Ayan, Nickolaevsk-on-Amur, Zolotoi, Ternei and Vladivostok); interior plains (Pogranichnyi, Khabarovsk and Poliny-Osipenko); and low elevation (<1000 m) highland (Bomnak, Ekimchan and Chekunda). These data consisted of year-long records from each site during 1966-2005. The minimum and maximum temperatures

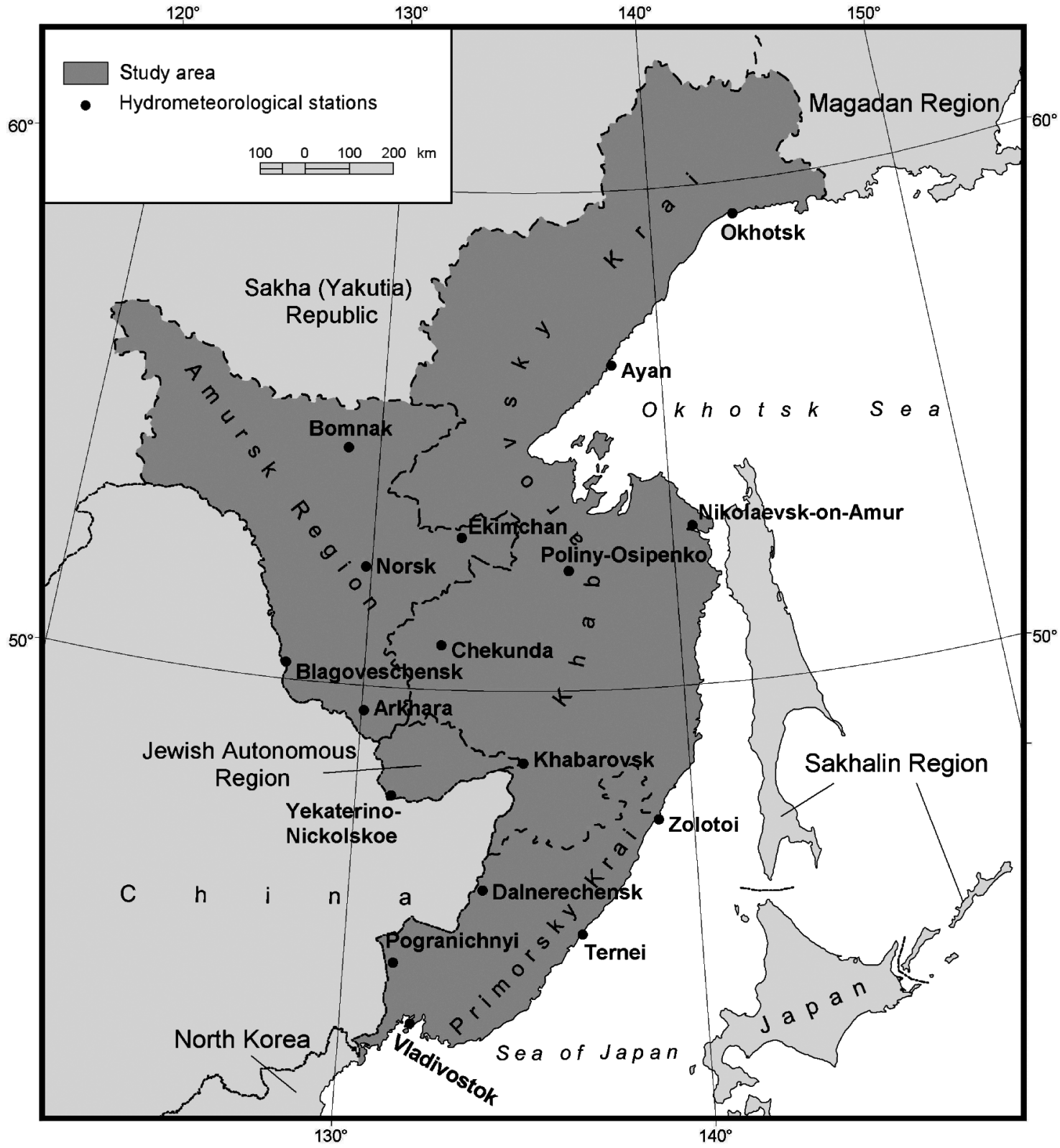

Fig. 2. The southern part of the Russian Far East showing the location of climate stations used in the present study 
Table 3. Climate stations in the Russian Far East used in the present study showing the mean annual ( $\left.T_{\text {year }}\right)$, minimum ( $\left.T_{\text {min }}\right)$ and maximum ( $\left.T_{\max }\right)$ temperatures and range for each station

\begin{tabular}{|lcccccccc|}
\hline Climate station & $\begin{array}{c}\text { Latitude } \\
\left({ }^{\circ} \mathrm{N}\right)\end{array}$ & $\begin{array}{c}\text { Longitude } \\
\left({ }^{\circ} \mathrm{E}\right)\end{array}$ & $\begin{array}{c}\text { Altitude } \\
(\mathrm{m})\end{array}$ & $\begin{array}{c}\text { WMO } \\
\text { index }\end{array}$ & $\begin{array}{r}T_{\text {year }} \\
\left({ }^{\circ} \mathrm{C}\right)\end{array}$ & $\begin{array}{c}T_{\min } \\
\left({ }^{\circ} \mathrm{C}\right)\end{array}$ & $\begin{array}{c}T_{\max } \\
\left({ }^{\circ} \mathrm{C}\right)\end{array}$ & $\begin{array}{c}\text { Annual temperature } \\
\text { range }\left({ }^{\circ} \mathrm{C}\right)\end{array}$ \\
\hline Okhotsk & $59^{\circ} 11^{\prime}$ & $143^{\circ} 12^{\prime}$ & 8 & 31088 & -4.8 & -22.5 & 13.1 & 35.6 \\
Ayan & $56^{\circ} 27^{\prime}$ & $138^{\circ} 09^{\prime}$ & 6 & 31168 & -3.1 & -19.2 & 13.2 & 32.4 \\
Bomnak & $54^{\circ} 43^{\prime}$ & $128^{\circ} 56^{\prime}$ & 357 & 31253 & -5.1 & -32.2 & 17.8 & 50.0 \\
Ekimchan & $53^{\circ} 04^{\prime}$ & $132^{\circ} 56^{\prime}$ & 540 & 31329 & -5.4 & -31.4 & 17.0 & 48.4 \\
Nickolaevsk-on-Amur & $53^{\circ} 09^{\prime}$ & $140^{\circ} 41^{\prime}$ & 46 & 31369 & -2.3 & -23.7 & 16.5 & 40.2 \\
Norsk & $52^{\circ} 21^{\prime}$ & $129^{\circ} 55^{\prime}$ & 207 & 31388 & -3.7 & -31.8 & 19.3 & 51.1 \\
Poliny-Osipenko & $52^{\circ} 25^{\prime}$ & $136^{\circ} 30^{\prime}$ & 73 & 31416 & -2.7 & -27.9 & 17.8 & 45.7 \\
Blagoveschensk & $50^{\circ} 16^{\prime}$ & $127^{\circ} 30^{\prime}$ & 130 & 31510 & 0.1 & -24.1 & 21.4 & 45.5 \\
Chekunda & $50^{\circ} 49^{\prime}$ & $132^{\circ} 10^{\prime}$ & 271 & 31532 & -4.4 & -33.8 & 18.9 & 52.7 \\
Arkhara & $49^{\circ} 25^{\prime}$ & $130^{\circ} 05^{\prime}$ & 133 & 31594 & -0.8 & -26.7 & 20.9 & 47.6 \\
Yekaterino-Nickolskoe & $47^{\circ} 44^{\prime}$ & $130^{\circ} 58^{\prime}$ & 72 & 31707 & 1.9 & -20.3 & 21.0 & 41.3 \\
Khabarovsk & $48^{\circ} 31^{\prime}$ & $135^{\circ} 10^{\prime}$ & 88 & 31735 & 1.4 & -22.3 & 21.1 & 43.4 \\
Zolotoi & $47^{\circ} 19^{\prime}$ & $138^{\circ} 59^{\prime}$ & 26 & 31829 & 2.2 & -11.9 & 16.3 & 28.2 \\
Dalnerechensk & $45^{\circ} 52^{\prime}$ & $133^{\circ} 44^{\prime}$ & 101 & 31873 & 2.2 & -20.5 & 21.1 & 41.6 \\
Ternei & $45^{\circ} 02^{\prime}$ & $136^{\circ} 40^{\prime}$ & 68 & 31909 & 3.4 & -12.1 & 17.5 & 29.6 \\
Pogranichnyi & $44^{\circ} 24^{\prime}$ & $131^{\circ} 23^{\prime}$ & 211 & 31915 & 5.7 & -15.1 & 21.3 & 36.4 \\
Vladivostok & $43^{\circ} 07^{\prime}$ & $131^{\circ} 53^{\prime}$ & 183 & 31960 & 5.0 & -13.1 & 21.0 & 34.1 \\
\hline
\end{tabular}

for each day were those measured by minimum and maximum thermometers. Mean daily air temperature was calculated using $3 \mathrm{~h}$ interval temperatures.

Data for 5 mo of the high-sun period of the year were used (May to September). Linear regression analysis was used to identify trends. The statistical significance of the trends was tested using the chi-squared test and the Fisher-Snedecor F-test. The level of significance was set to $\mathrm{p} \leq 0.05$. Calculated $F$-values were compared with empirical $F$-values equal to 4.08 for the 40 yr series.

\section{RESULTS}

GDDs were calculated for each location within the Russian Far East region using base temperatures described earlier (Fig. 3, Table 4). First we used the $0^{\circ} \mathrm{C}$ base (GDD0) to mark the commencement of the warm season or growing season. The highest values appeared at the continental location of Pogranichnyi in the southern part of the study area, where a GDD of 3212 was found. This is more than twice that the value at Okhotsk (GDD0 = 1459), a coastal location in the north of the region still under the influence of cold maritime air. This pattern was seen elsewhere, in high GDDs at the continental stations in the south, namely, Dalnerechensk, Yekaterino-Nickolskoe, Blagoveschensk and Khabarovsk. GDDs for the coastal areas were considerably lower, ranging from 1530 at Ayan at northern coast of the Okhotsk Sea to 2208 at Zolotoi and 2968 at Vladivostok on southern coast of the Japan Sea. The elevated locations at Bomnak and Ekimchan showed intermediate GDDs of 2236 and 2114, respectively (Fig. 3, Table 4).
The $5^{\circ} \mathrm{C}$ GDD base temperature (GDD5) indicates the start of period of active plant growth. The spatial distribution of GDD5 is similar to that of GDD0. Values of GDD5 ranged from 767 at Okhotsk in the northern coastal part of the study area to almost 3 times this value (GDD5 $=2246$ ) at the continental location of Pogranichnyi to the south. Throughout, continental areas had higher GDD5 values than coastal locations (Fig. 3, Table 4).

The spatial variability of GDD10 characterizes the beginning of the main growth period for the main coldresistant plants and, thus, active plant growth for most agricultural crops. The highest value was found at Pogranichnyi (1416), a GDD10 five times greater than that for Okhotsk (290). There were large differences in GDD10 between continental and coastal locations at the same latitude; e.g. the GDD10 at Yekaterino-Nickolskoe was 2.3 times that of Zolotoi. The far north continental stations are on elevated land, where the contrast with the coastal stations is not as large (Fig. 3, Table 4).

Climatic conditions best suited to heat-loving plants are described by GDD15. The difference in GDD15 between the north and south of the region varied by up to a factor of 11, ranging from 67 at Okhotsk to 771 at Pogranichnyi, which is a manifestation of the great contrast in conditions between the 2 geographical extremes in summer. The spatial patterns were similar to those described for GDD0, GDD5 and GDD10, but with a significant reduction in the absolute values.

Year-to-year fluctuations in GDDs can differ greatly from the period mean values. The root mean square deviation (RMSD) and coefficient of variation (CV) of GDD are used as a measure of temporal variability. 


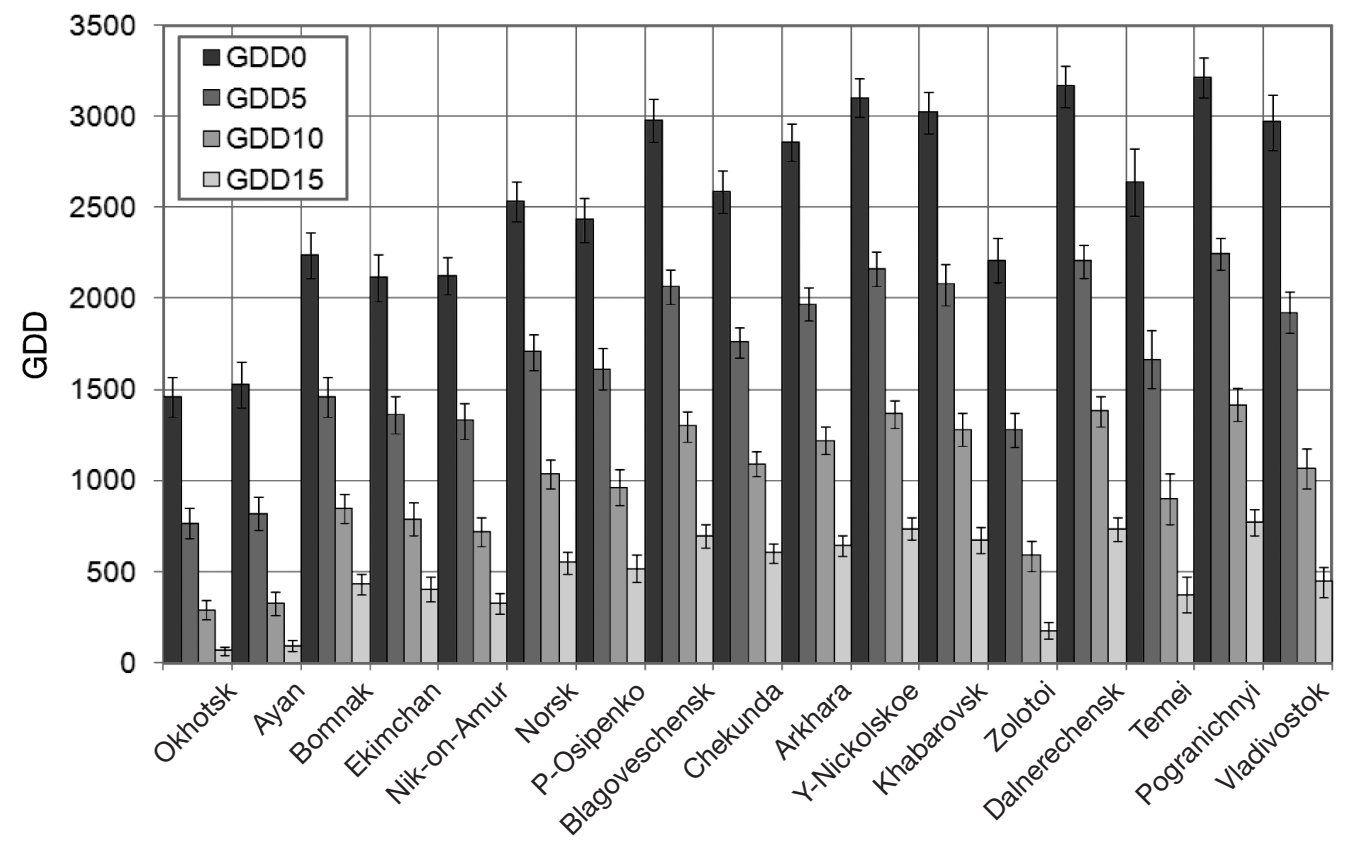

Fig. 3. Growing degree-days (GDD) for 17 climate stations in the Russian Far East for the period 1966-2005 for 4 thresholds: GDD0, GDD5, GDD10 and GDD15

The results show that $\mathrm{SD}$ and $\mathrm{CV}$ differ from place to place and indicate changeable interannual variability of GDD (Fig. 3, Table 4).

The CV is more informative as it gives an indication of relative temporal variability. The results show that variability increases from the lower thermal base (GDD0) to the highest (GDD15), indicating the unreliability of thermal climatic resources during the summer period (Table 4). Also apparent is the spatial variability in $\mathrm{CV}$, with higher values at coastal locations; e.g. Ternei, Zolotoi and Vladivostok, and especially in the north at Ayan, Okhotsk and Nikolayevsk-on-Amur. This may be explained by the influence of oceanic air.

To explore how these results are related to the mean temperature of the growing season, the mean temperature for the 5 warm-season months May to September (T59) was estimated using 2 methods. The first method (T59 1 , Eq. 5) calculated the mean of eight $3 \mathrm{~h}$ interval temperatures and the second (T59 $9_{2}$ Eq. 6) calculated the mean of minimum - maximum values. The results summarized in Table 5 show that the particular method used is important, as there are comparatively

Table 4. Growing degree-days (GDD \pm RMSD) (1) and CV for various GDD agro-climate indices for the period 1966-2005 in the Russian Far East

\begin{tabular}{|c|c|c|c|c|c|c|c|c|}
\hline \multirow[t]{2}{*}{ Climate station } & \multicolumn{2}{|c|}{- GDD0 } & \multicolumn{2}{|c|}{- GDD5 -} & \multicolumn{2}{|c|}{$-\operatorname{GDD} 10-$} & \multicolumn{2}{|c|}{- GDD15 } \\
\hline & GDD & $\mathrm{CV}$ & GDD & $\mathrm{CV}$ & GDD & $\mathrm{CV}$ & GDD & $\mathrm{CV}$ \\
\hline Okhotsk & $1438 \pm 100$ & 7.7 & $756 \pm 86$ & 11.1 & $285 \pm 47$ & 18.3 & $64 \pm 20$ & 32.3 \\
\hline Ayan & $1498 \pm 112$ & 8.0 & $792 \pm 91$ & 11.9 & $308 \pm 63$ & 20.1 & $86 \pm 29$ & 32.4 \\
\hline Bomnak & $2213 \pm 125$ & 5.6 & $1441 \pm 108$ & 7.3 & $836 \pm 86$ & 9.8 & $427 \pm 61$ & 13.3 \\
\hline Ekimchan & $2073 \pm 120$ & 6.1 & $1329 \pm 102$ & 8.3 & $759 \pm 78$ & 11.4 & $384 \pm 54$ & 16.0 \\
\hline Nickolaevsk-on-Amur & $2109 \pm 106$ & 4.7 & $1316 \pm 98$ & 7.0 & $710 \pm 84$ & 11.2 & $319 \pm 58$ & 17.8 \\
\hline Norsk & $2500 \pm 114$ & 4.3 & $1678 \pm 99$ & 5.6 & $1009 \pm 80$ & 7.7 & $528 \pm 59$ & 10.9 \\
\hline Poliny-Osipenko & $2385 \pm 123$ & 5.1 & $1572 \pm 114$ & 7.0 & $931 \pm 100$ & 10.2 & $496 \pm 75$ & 14.0 \\
\hline Blagoveschensk & $2928 \pm 111$ & 3.8 & $2027 \pm 95$ & 4.8 & $1265 \pm 79$ & 6.4 & $672 \pm 59$ & 9.3 \\
\hline Chekunda & $2543 \pm 100$ & 4.5 & $1727 \pm 86$ & 4.7 & $1062 \pm 72$ & 6.3 & $581 \pm 55$ & 8.6 \\
\hline Arkhara & $2828 \pm 108$ & 3.6 & $1942 \pm 92$ & 4.5 & $1196 \pm 78$ & 6.1 & $624 \pm 60$ & 9.2 \\
\hline Yekaterino-Nickolskoe & $3087 \pm 108$ & 3.4 & $2153 \pm 94$ & 4.1 & $1358 \pm 84$ & 5.6 & $732 \pm 69$ & 8.6 \\
\hline Khabarovsk & $2985 \pm 128$ & 3.8 & $2045 \pm 114$ & 5.0 & $1254 \pm 101$ & 7.0 & $649 \pm 80$ & 10.5 \\
\hline Zolotoi & $2179 \pm 116$ & 5.5 & $1249 \pm 95$ & 8.1 & $567 \pm 72$ & 13.8 & $168 \pm 43$ & 27.2 \\
\hline Dalnerechensk & $3123 \pm 108$ & 3.5 & $2165 \pm 90$ & 4.3 & $1351 \pm 81$ & 5.9 & $714 \pm 66$ & 8.6 \\
\hline Ternei & $2558 \pm 167$ & 7.0 & $1594 \pm 158$ & 10.2 & $841 \pm 134$ & 15.7 & $336 \pm 94$ & 25.5 \\
\hline Pogranichnyi & $3173 \pm 103$ & 3.5 & $2202 \pm 89$ & 4.7 & $1381 \pm 79$ & 6.5 & $744 \pm 67$ & 9.5 \\
\hline Vladivostok & $2918 \pm 123$ & 5.1 & $1879 \pm 111$ & 7.0 & $1032 \pm 94$ & 10.3 & $424 \pm 69$ & 18.8 \\
\hline
\end{tabular}


Table 5. Mean monthly temperatures from May to September (T59) for the period 1966-2005 for 17 climate stations in the Russian Far East, calculated using 2 methods, T59 ${ }_{1}$ and T59 $9_{2}$ (see Section 2.3 for details). Also shown is the difference between methods and their correlation coefficients (r)

\begin{tabular}{|lcccc|}
\hline \multirow{2}{*}{ Climate station } & \multicolumn{2}{c}{$\mathrm{T} 59 \pm \mathrm{SD}\left({ }^{\circ} \mathrm{C}\right)$} & $\begin{array}{c}\text { Difference } \\
\text { T59 }\end{array}$ & $\mathrm{r}$ \\
& & $\mathrm{T} 59_{2}$ & $\mathrm{~T} 59_{2}-\mathrm{T} 59_{1}\left({ }^{\circ} \mathrm{C}\right)$ & \\
\hline Okhotsk & $8.9 \pm 0.8$ & $9.2 \pm 0.6$ & 0.3 & 0.986 \\
Ayan & $9.2 \pm 0.8$ & $9.5 \pm 0.8$ & 0.4 & 0.993 \\
Bomnak & $13.2 \pm 0.8$ & $13.5 \pm 0.8$ & 0.3 & 0.983 \\
Ekimchan & $12.2 \pm 0.8$ & $12.9 \pm 0.8$ & 0.7 & 0.987 \\
Nickolaevsk-on-Amur & $11.9 \pm 0.7$ & $12.6 \pm 0.7$ & 0.7 & 0.979 \\
Norsk & $14.8 \pm 0.6$ & $15.0 \pm 0.6$ & 0.2 & 0.986 \\
Poliny-Osipenko & $13.9 \pm 0.8$ & $14.7 \pm 0.8$ & 0.8 & 0.984 \\
Blagoveschensk & $17.5 \pm 0.6$ & $17.8 \pm 0.6$ & 0.4 & 0.990 \\
Chekunda & $14.6 \pm 0.6$ & $15.4 \pm 0.6$ & 0.8 & 0.937 \\
Arkhara & $16.6 \pm 0.6$ & $16.6 \pm 0.6$ & 0.1 & 0.979 \\
Yekaterino-Nickolskoe & $17.3 \pm 0.6$ & $18.0 \pm 0.6$ & 0.7 & 0.986 \\
Khabarovsk & $17.0 \pm 0.7$ & $17.4 \pm 0.7$ & 0.4 & 0.990 \\
Zolotoi & $12.4 \pm 0.6$ & $12.7 \pm 0.6$ & 0.3 & 0.937 \\
Dalnerechensk & $17.6 \pm 0.6$ & $18.1 \pm 0.6$ & 0.5 & 0.986 \\
Ternei & $14.2 \pm 0.9$ & $15.1 \pm 1.0$ & 0.9 & 0.993 \\
Pogranichnyi & $17.2 \pm 0.6$ & $17.9 \pm 0.6$ & 0.7 & 0.986 \\
Vladivostok & $15.8 \pm 0.7$ & $16.5 \pm 0.7$ & 0.7 & 0.993 \\
\hline
\end{tabular}

large differences in the values for $\mathrm{T} 59_{1}$ and $\mathrm{T} 59_{2}$. This finding is at odds with that of Gilmore \& Rogers (1958) described earlier.

Spatial patterns of T59 are very similar to those for GDD, with lower temperatures to the north, on coastal land and in elevated terrain. Results show that mean temperatures calculated from maximum and minimum values $\left(\mathrm{T}_{5} \mathrm{~g}_{2}\right)$ for the same day are higher than those computed using $3 \mathrm{~h}$ interval data (T59) at all climate stations, but with a high degree of correlation (Table 5). We cannot find any explanation for the spatial disparity in differences between $\mathrm{T} 59_{2}$ and $\mathrm{T} 59_{1}$. It might be due microclimatic differences between climate stations or inhomogeneities in the data.

We also examined correlations between GDD and T59 using T59 ${ }_{2}$ (Table 6). Inspection of Table 6 shows a strong relationship between these variables. For each location there is a particular GDD threshold category that corresponds with the thermal conditions characteristic of the region. For example, Okhotsk is located in the cooler north of the study region, where T59 is closer to GDD0, whereas Dalnerechensk is located in the warmer southern area, where T59 is closer to GDD15.

Scattergrams of GDDs against T59 using mean station values were also used to examine the relationship between the 2 variables (Fig. 4). Fig. 4 reveals the strongest relationship between GDD0, GDD5, GDD10 and GDD15 and T59 for data from 17 stations $\left(\mathrm{R}^{2}=\right.$ $0.99,0.99,0.97$ and 0.89 , respectively), showing spatial coherence.
The next step was to examine the data for temporal changes. Simple linear trends over the period 1966-2005 were estimated by regression for each station for each of the 5 variables: GDD0, GDD5, GDD10, GDD15 and T59. These values were multiplied by 40 to extend the trend statistics over the $40 \mathrm{yr}$ data period (Table 7). The steepest trend occurred in the case of Ternei and the smallest in the case of Nickolaevsk-on-Amur. The significance of the trends was tested using the Fisher-Snedecor $F$-test.

Calculated $F$-values show that T59 and GDD at all thresholds are significant (i.e. greater than empirical $F$-value of 4.08 , data not shown) for all GDD and T59-series at the northern coastal stations (Okhotsk and Ayan) and 2 continental stations (Poliny-Osipenko and Blagoveschensk), and for all southern climate stations - coastal (Zolotoi, Ternei and Vladivostok) and continental (Dalnerechensk and Pogranichnyi). The results show statistically significant positive trends at these regions. However, this was not the case for the coastal Nickolaevsk-on-Amur and continental climate stations (Bomnak, Ekimchan, Norsk, Chekunda, Arkhara, Yekaterino-Nickolskoe and Khabarovsk). An example of typical trends in GDD is shown in Fig. 5 for Yekaterino-Nickolskoye for the period 1966-2005. Generally speaking, there is warming in some regions but not others, though everywhere GDD0 shows the most significant positive temporal change.

Table 6. Correlations between growing degree-day (GDD) and mean monthly temperatures from May to September (T59) for the period 1966-2005 for 17 climate stations in the

Russian Far East. Bold: highest value (r) for each location

\begin{tabular}{|lcccc|}
\hline Climate station & GDD0 & GDD5 & GDD10 & GDD15 \\
\hline Okhotsk & $\mathbf{0 . 9 7 0}$ & 0.954 & 0.885 & 0.552 \\
Ayan & 0.960 & $\mathbf{0 . 9 7 2}$ & 0.873 & 0.684 \\
Bomnak & 0.937 & $\mathbf{0 . 9 6 5}$ & 0.947 & 0.875 \\
Ekimchan & 0.930 & $\mathbf{0 . 9 3 1}$ & 0.896 & 0.825 \\
Nickolaevsk-on-Amur & 0.940 & $\mathbf{0 . 9 7 2}$ & 0.939 & 0.890 \\
Norsk & 0.939 & $\mathbf{0 . 9 4 0}$ & 0.936 & 0.885 \\
Poliny-Osipenko & 0.932 & $\mathbf{0 . 9 5 9}$ & 0.953 & 0.928 \\
Blagoveschensk & 0.891 & 0.940 & 0.953 & $\mathbf{0 . 9 5 7}$ \\
Chekunda & 0.900 & 0.907 & $\mathbf{0 . 9 1 4}$ & 0.873 \\
Arkhara & 0.897 & 0.923 & $\mathbf{0 . 9 4 0}$ & 0.931 \\
Yekaterino-Nickolskoe & 0.856 & 0.909 & $\mathbf{0 . 9 2 6}$ & 0.900 \\
Khabarovsk & 0.893 & 0.943 & $\mathbf{0 . 9 6 2}$ & 0.958 \\
Zolotoi & 0.913 & 0.962 & $\mathbf{0 . 9 6 5}$ & 0.853 \\
Dalnerechensk & 0.871 & 0.899 & 0.930 & $\mathbf{0 . 9 3 1}$ \\
Ternei & 0.953 & 0.969 & $\mathbf{0 . 9 7 8}$ & 0.969 \\
Pogranichnyi & 0.821 & 0.879 & $\mathbf{0 . 9 1 4}$ & 0.913 \\
Vladivostok & 0.889 & 0.937 & $\mathbf{0 . 9 6 7}$ & 0.908 \\
\hline
\end{tabular}



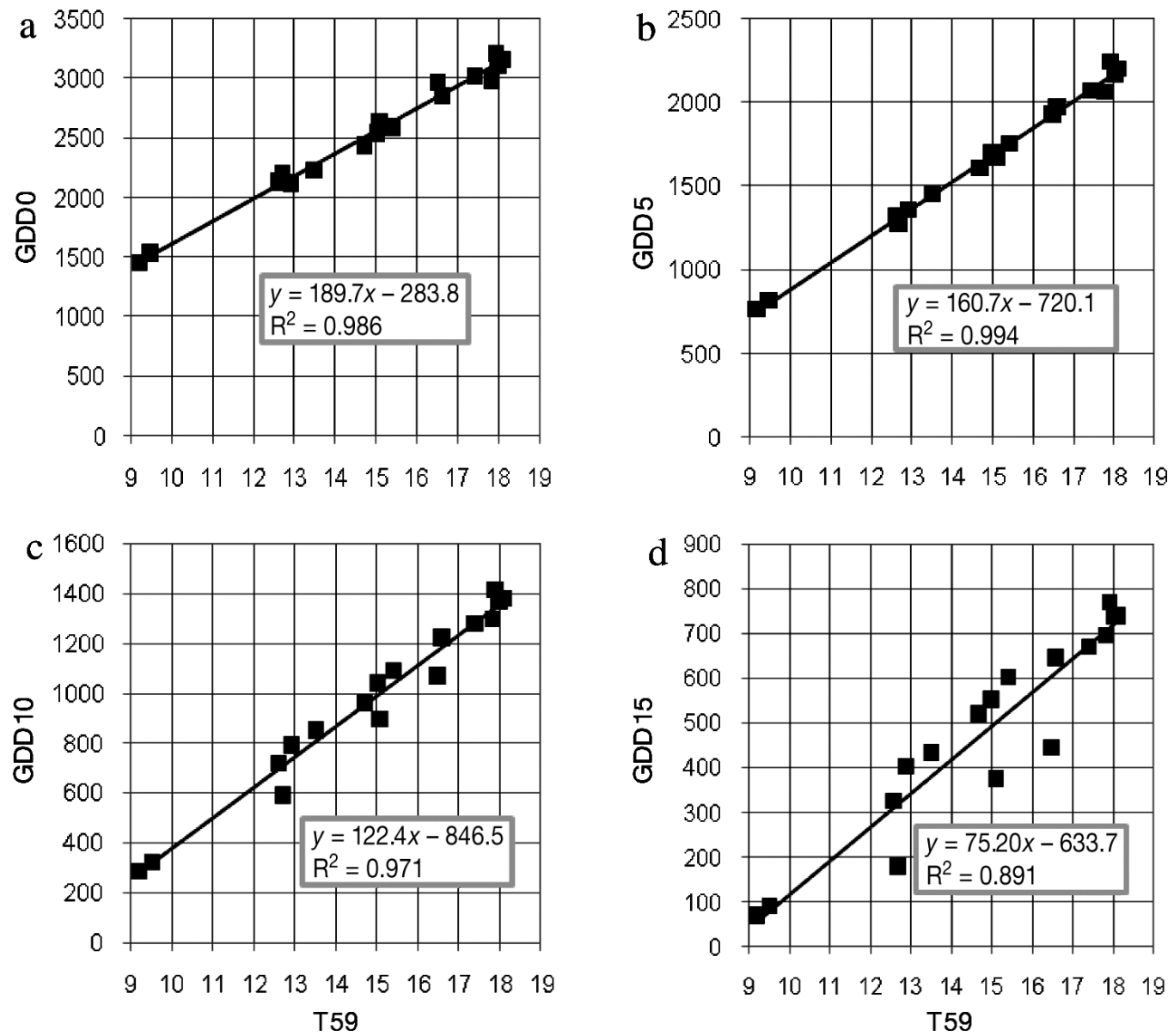

Fig. 4. Scatterplots of growing degree-days (GDD) versus mean monthly temperatures from May to September (T59) for climate stations in the study region for the period 1966-2005: (a) GDD0, (b) GDD5, (c) GDD10 and (d) GDD15

Table 7. Linear trends for growing degree-day (GDD) and mean monthly temperature of the growing season (T59) for the $40 \mathrm{yr}$ period 1966-2005 in the Russian Far East

\begin{tabular}{|lrrrrr|}
\hline \multirow{2}{*}{ Climate station } & \multicolumn{5}{c}{ Linear trend $\left({ }^{\circ} \mathrm{C}\right)$} \\
& GDD0 & GDD5 & GDD10 & GDD15 & T59 \\
\hline Okhotsk & 225 & 161 & 96 & 26 & 1.36 \\
Ayan & 227 & 186 & 113 & 42 & 1.48 \\
Bomnak & 92 & 76 & 36 & 2 & 0.56 \\
Ekimchan & 165 & 144 & 107 & 68 & 1.08 \\
Nickolaevsk-on-Amur & 20 & 14 & 11 & 10 & 0.16 \\
Norsk & 107 & 104 & 85 & 63 & 0.52 \\
Poliny-Osipenko & 209 & 177 & 121 & 66 & 1.20 \\
Blagoveschensk & 200 & 169 & 133 & 88 & 1.04 \\
Chekunda & 105 & 85 & 68 & 43 & 0.80 \\
Arkhara & 110 & 97 & 67 & 56 & 0.52 \\
Yekaterino-Nickolskoe & 116 & 88 & 53 & 14 & 0.64 \\
Khabarovsk & 124 & 99 & 76 & 53 & 0.44 \\
Zolotoi & 201 & 185 & 136 & 50 & 0.96 \\
Dalnerechensk & 199 & 182 & 138 & 78 & 0.92 \\
Ternei & 498 & 464 & 368 & 230 & 2.52 \\
Pogranichnyi & 173 & 168 & 132 & 74 & 0.60 \\
Vladivostok & 274 & 239 & 175 & 93 & 0.96 \\
\hline
\end{tabular}

\section{DISCUSSION}

The mean value of GDDs varied considerably from region to region, but by and large followed the main geographical pattern of temperature distribution: the magnitude of GDD increased from north to south and decreased towards the coast as well as from elevated land areas to the plains. The largest contrast occurred between Pogranichnyi $\left(44^{\circ} 24^{\prime} \mathrm{N}\right)$ and Okhotsk $\left(59^{\circ} 11^{\prime} \mathrm{N}\right)$. This spatial difference in thermal supply increased from the warm period to summer by a factor of 2 to 11 . The most noticeable spatial gradient occurred at locations at similar latitudes, which is explained by the distance from Pacific coastal waters. For example, the gradient contrast for all degree days (GDD0, GDD5, GDD10 and GDD15) between YekaterinoNickolskoe (inland continental, $47^{\circ} 44^{\prime} \mathrm{N}$ 


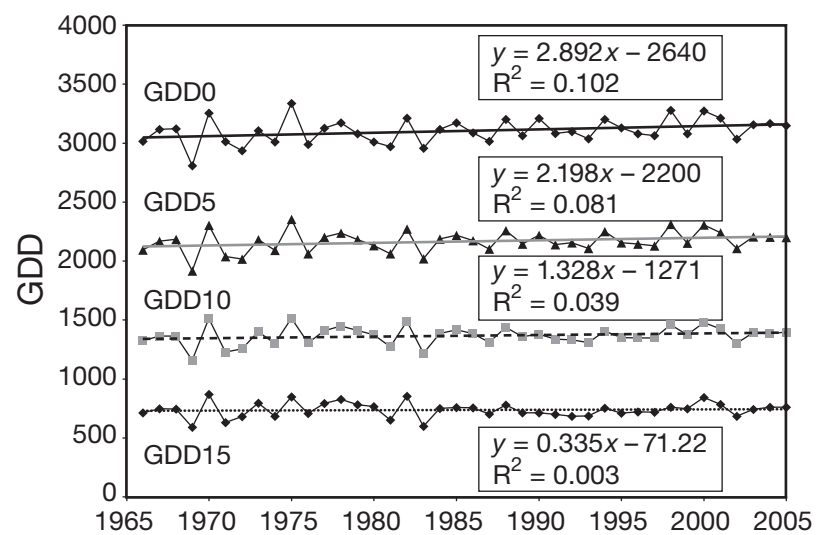

Fig. 5. Temporal distribution of growing degree-days (GDD) at Yekaterino-Nickolskoye for the period 1966-2005

and $130^{\circ} 58^{\prime} \mathrm{E}$ ) and Zolotoi (coastal, $47^{\circ} 19^{\prime} \mathrm{N}$ and $138^{\circ} 59^{\prime} \mathrm{E}$ ) was 1.4, 1.7, 2.3 and 4.2 times, respectively. The gradient was reduced further to the north due to the influence of elevated terrain and its spatial distribution. For example, the GDD gradient contrast from Bomnak (54 $43^{\prime} \mathrm{N}, 128^{\circ} 56^{\prime} \mathrm{E}, 357 \mathrm{~m}$ above sea level) to Nickolaevsk-on-Amur $\left(53^{\circ} 09^{\prime} \mathrm{N}, 140^{\circ} 41^{\prime} \mathrm{E}, 46 \mathrm{~m}\right.$ above sea level) was 1.05, 1.1, 1.2 and 1.3 times, respectively (Table 4 ).

The strong correlation between GDD and T59 for the study region has important implications for agricultural management. Jones \& Briffa (1995) suggest T59 data may be used for estimation of GDD5 in the regions of the world where data are not available for calculation of GDD. The results of the present study show this to be the case, although this depends on the thresholds used, shown by the correlation coefficients for the various GDD categories and T59 (Table 6, Fig. 4). In summary, GDD0 may be approximated by the average monthly temperature T59 at Okhotsk, the northernmost station; GDD5 by T59 at Ayan, Bomnak, Nickolaevsk-on-Amur, Poliny-Osipenko and vicinity, GDD10 by T59 at southern stations such as Yekaterino-Nickolskoye, Khabarovsk, Pogranichnyi and vicinity; and GDD15 by T59 at Blagoveschensk and Dalnerechensk, the southernmost stations.

Temporal trends in both GDD and T59 show mainly positive changes over the 1966-2005 period, confirming what may be part of a general global warming trend. The largest positive trend was observed for GDD0, indicating increasing heat accumulation for the warm season. In contrast, GDD15 showed little change, indicating heat accumulation at higher thresholds levels have not changed significantly. Both of these trends imply warmer spring periods but not warmer summers. The biggest increase in temperature occurred in the south near Ternei, which showed a strong positive trend.
There are no comparable studies in the literature on similar climate regions and at equivalent latitudes. Future studies such as this may produce data sets on which comparisons can be usefully made.

\section{CONCLUSIONS}

The objective of the present study was to develop a GDD tool as an agro-climate indicator and describe its implementation with daily time series for a thermally extreme mid-latitude climate where this has not previously been studied. Typically, in regions with very low cold-season temperatures, summer temperatures are also relatively low. For the climate examined here, the opposite is the case. The study area is characterized by extremely low temperatures during the lowsun period of the year but also very high temperatures during the high-sun period of the year. Results can be used to explore how these climatic characteristics are related to the mean temperature of the growing season, and will provide valuable information for agricultural management.

The results show the mean values of various categories of GDD vary considerably from one location to another. Generally, GDD unit accumulations increased from north to south, from interior continental locations to the coast and from mountainous locations to the plains. Thermal conditions in the southern part of the study area meet the growth requirements of all the plants cultivated there, which include wheat, corn, soybeans, vegetables and even rice at the warmest locations. Low thermal resources observed in the north, in the elevated areas and in the coastal regions are only sufficient for growing vegetables in greenhouses, as well as some forage crops and potatoes.

Temporal variability of GDD and average temperature between May and September showed principally positive temporal changes over the period 1966-2005, confirming a general warming trend. The most significant positive trend was observed for GDD0, indicating that the study region has experienced an increase in duration of the 'warm season'. By contrast, GDD15 shows little change, indicating heat accumulation at higher threshold levels has not changed significantly.

Generally speaking, estimates of biologically active temperature accumulation have a variety of uses. While GDD cannot be forecasted, climate data archives can be used to assess growth potential and provide a measure of the probability of success for particular crop. For example, a particular area may have a GDD10 of 1400. If the crop to be grown requires a minimum of 1200 GDD, the frequency (number of years) with 
which this occurs, and thus its probability of occurrence, can be estimated and its acceptability assessed for farm investment. Future research comparing GDD with other measures such as $T_{\mathrm{ac}}$ may provide further insights into ways of assessing the agricultural potential of climatic resources and comparing the length of growing periods and their relationships to higher annual temperatures.

Acknowledgements. The work was supported by the Russian Fund for Basic Research (project nos. 08-01-98505-r_vostok_a and 09-04-00146-a) and the Far Eastern Branch of the Russian Academy of Sciences (project nos. 09-I-П16-08, and 09-III-A09-498).

\section{LITERATURE CITED}

Baskerville GL, Emin P (1969) Rapid estimation of heat accumulation from maximum and minimum temperatures. Ecology 50:514-517

Bootsma A (1994) Long term (100 yr) climatic trends for agriculture at selected locations in Canada. Clim Change 26: $65-88$

Bootsma A, Anderson D, Gameda S (2004) Potential impacts of climate change on agroclimatic indices in southern regions of Ontario and Quebec. Technical Bulletin ECORC Contribution No.03-284, Eastern Cereal and Oilseed Research Centre, Agriculture and Agri-Food, Ottawa

Brown DM (1960) Soybean ecology. I. Development temperature relationships from controlled environment studies. Agron J 52:493-496

Cesaraccio C, Spano D, Duce P, Snyder RL (2001) An improved model for determining degree-day values from daily temperature data. Int J Biometeorol 45:161-169

> Chen CS (1973) Digital computer simulation of heat units and their use for predicting plant maturity. Int J Biometeorol 17:329-335

Chirkov YuI (1965) Agrometeorological indices in the development and formation of maize crops. Agric Meteorol 2: $121-126$

Cross HZ, Zuber MS (1972) Prediction of flowering dates in maize based on different methods of estimating thermal units. Agron J 64:351-355

Darby HM, Lauer JG (2002) Harvest date and hybrid influence on corn forage yield, quality and preservation. Agron J 94:559-566

Davitaya FF (1965) A method of predicting heat supply and duration of the growth period. Agric Meteorol 2:109-119

Dwyer LM, Steward DW, Carrigan L, Ma BL, Neave P, Balchin D (1999) Guidelines for comparisons among different maize maturity rating systems. Agron J 91:946-949

Easterling WE, Kates RW (1995) Indexes of leading climate indicators for impact assessment. Clim Change 31: 623-648

Edey SN (1977) Growing degree-days and crop production in Canada. Publication 1635, Department of Agriculture, Ottawa

Fealy R, Fealy RM (2008) The spatial variation in degree days derived from locational attributes for the 1961 to 1990 period. Ir J Agric Food Res 47:1-11

Folland CK, Karl TR, Vinnikov KYa (1990) Observed climate variation and change. In: Houghton JT, Jenkins GJ, Ephraums JJ (eds) Climate change: the IPCC scientific assessment. Cambridge University Press, Cambridge, p 195-238

Folland CK, Karl TR, Nicholls N, Nyenzi BS, Parker DE, Vinnikov KYa (1992) Observed climate change and variability. In: Houghton JT, Callendar BA, Varney SK (eds) Climate change 1992: the supplementary report to the IPCC Scientific Assessment. Cambridge University Press, Cambridge, p 136-170

Førland EJ, Skaugen TE, Benestad RE, Hanssen-Bauer I, Tveito OE (2004) Variations in thermal growing, heating, and freezing indices in the Nordic Arctic, 1900-2050. Arct Antarct Alp Res 36:347-356

> Gavilán RG (2005) The use of climatic parameters and indices in vegetation distribution. A case study in the Spanish Sistema Central. Int J Biometeorol 50:111-120

Gilmore EC Jr, Rogers JS (1958) Heat units as a method of measuring maturity in corn. Agron J 50:611-615

Gordeev AV, Kleschenko AD, Chernyakov BA, Sirotenko OD (2006) Bioclimatic potential of Russia: theory and practice. Tovarischestvo nauchnykh izdanyi KMK, Moscow (in Russian)

Gordon R, Bootsma A (1993) Analyses of growing degreedays for agriculture in Atlantic Canada. Clim Res 3: 169-176

Grigorieva E (2008) Spatial-temporal dynamics of climate thermal resources for the southern part of the Russian Far East. 18th International Congress of Biometeorology, Tokyo, 22-26 Sep 2008. International Society of Biometeorology, Tokyo, p 121

- Idso SB, Jackson RD, Reginato RJ (1978) Extending the 'degree day' concept of plant phenological development to include water stress effects. Ecology 59:431-433

Jones PD (1994) Hemispheric surface air temperature variations: a reanalysis and an update to 1993. J Clim 7: 1794-1802

Jones PD, Briffa KR (1992) Global surface air temperature variations. 1. The instrumental period. Holocene 2:174-188

$>$ Jones PD, Briffa KR (1995) Growing season temperatures over the former Soviet Union. Int J Climatol 15:943-959

Karing P, Kallis A, Tooming H (1999) Adaptation principles of agriculture to climate change. Clim Res 12:175-183

Karl TR, Jones PD, Knight RW, Kukla G and others (1993) Asymmetric trends of daily maximum and minimum temperature. Bull Am Meteorol Soc 74:1007-1023

Kelchevskaya LS (1971) Methods for observation processing in agrometeorology (in Russian). Hydrometeoizdat, Leningrad

Matzarakis A, Ivanova D, Balafoutis C, Makrogiannis T (2007) Climatology of growing degree days in Greece. Clim Res 34:233-240

McMaster GS, Smika DE (1988) Estimation and evaluation of winter wheat phenology in the central Great Plains. Agric Meteorol 43:1-18

> McMaster GS, Wilhelm WW (1997) Growing degree-days: one equation, two interpretations. Agric Meteorol 87: 291-300

Mederski HJ, Miller ME, Weaver CR (1973) Accumulated heat units for classifying corn hybrid maturity. Agron J 65:743-747

Roltsch WJ, Zalom FG, Strawn AJ, Strand JF, Pitcairn MJ (1999) Evaluation of several degree-day estimation methods in California climates. Int J Biometeorol 42:169-176

Russelle MP, Wilhelm WW, Olson RA, Power JF (1984) Growth analysis based on degree days. Crop Sci 24:28-32

Sands PJ, Hacket C, Nix HA (1979) A model of the development and bulking of potatoes (Solanum tuberosum L.). Derivation from well-managed field crops. Field Crops 
Res 2:309-331

Schwartz MD, Ahas R, Aasa A (2006) Onset of spring starting earlier across the Northern Hemisphere. Global Change Biol 12:343-351

Smith PJ, Bootsma A, Gates AD (1982) Heat units in relation to corn maturity in the Atlantic region of Canada. Agric Meteorol 26:201-213

Snyder RL, Spano D, Cesaraccio C, Duce P (1999) Determining degree-day thresholds from field observations. Int J Biometeorol 42:177-182

Editorial responsibility: Mikhail Semenov,

Harpenden, UK
Vedin H (1990) Frequency of rare weather events during periods of extreme climate. Geogr Ann 72:151-155

Wang JY (1960) A critique of the heat-unit approach to plant response studies. Ecology 41:785-790

Wielgolaski FE (1999) Starting dates and basic temperatures in phenological observations of plants. Int $\mathrm{J}$ Biometeorol 42:158-168

Wiggans SC (1956) The effect of seasonal temperatures on maturity of oats planted at different dates. Agron J 48: $21-25$

Submitted: August 3, 2009; Accepted: June 4, 2010

Proofs received from author(s): June 24, 2010 